\title{
The role of hematopoietic stem cell transplantation in chronic myeloid leukemia
}

\author{
Alois Gratwohl • Helen Baldomero • Jakob Passweg
}

Received: 15 July 2014 / Accepted: 7 December 2014

(C) Springer-Verlag Berlin Heidelberg 2015

\begin{abstract}
Allogeneic hematopoietic stem cell transplantation (HSCT) is currently recommended as 2nd or 3rd line therapy for patients with chronic myeloid leukemia (CML) in first chronic phase or as salvage for patients with very advanced disease. As a consequence, numbers of HSCT in chronic phase have dropped significantly since the introduction of tyrosine kinase inhibitors (TKI), numbers of transplants in advanced disease to a lesser extent. These current recommendations consider primarily disease risk, defined as failure of TKI therapy; they might need to be adapted. We propose a more balanced appraisal of HSCT for individual patients which should include disease risk, transplant risk, and macroeconomic aspects. HSCT should be integrated into the treatment algorithms from diagnosis and be considered very early at first TKI failure for patients with high disease but low transplant risk. For patients with very advanced disease and high transplant risk in contrast, HSCT might only be recommended in a restricted research setting.
\end{abstract}

Keywords Chronic myeloid leukemia $\cdot$ Hematopoietic stem cell transplantation $\cdot$ Allogeneic $\cdot$ Autologous $\cdot$ Risk assessment

\section{Introduction}

Chronic myeloid leukemia (CML) has seen unprecedented changes over the last decade. The introduction of tyrosine kinase inhibitors (TKI) has changed the outlook for patients

\footnotetext{
A. Gratwohl $(\bowtie) \cdot H$. Baldomero $\cdot$ J. Passweg

Hematology, University Hospital, Dittingerstrasse 4, 4053 Basel, Switzerland

e-mail: alois.gratwohl@unibas.ch
}

with this previously uniformly fatal disease. The ease of application, the rapid response, and the mostly excellent tolerability by the patients has focused interest on targeted drug therapy [1-7]. Hematopoietic stem cell transplantation (HSCT) has lost its former importance as the "only curative therapy" [8-12]. This is reflected by the numbers of publications in medical journals or by the numbers of presentation on the topic at scientific or promotional meetings. If any, it is considered by many as tool of last resort when everything else has failed. This phenomenon is not restricted to CML. Ease of application and improved response to modern drug therapy has almost halted HSCT for multiple myeloma and limited HSCT to selected patients $[13,14]$. Still, HSCT is the most powerful intervention; it holds the potential for "cure" and outcome has dramatically improved over the last years $[15$, 16]. It might be good to look at the past and to reconsider the current status and the potential role of HSCT in the treatment algorithm of CML today.

\section{Evolution of HSCT for CML}

Historical perspective: the role model of CML for HSCT

The first report of a successful HSCT from a syngeneic donor to a patient with CML dramatically changed the concept on how to look at CML. For the first time, it became possible to achieve a $\mathrm{Ph}$ state, to eradicate the malignant $\mathrm{BCR} / \mathrm{ABL}$ clone, and to reverse the previously inexorable course of the disease [17]. The concept was rapidly taken up and extended to HSCT from an HLA-identical sibling donor. It did coincide with the introduction of cyclosporine $\mathrm{A}$ as novel and most powerful tool for the prevention of graft-versus-host disease (GvHD) and the concept of HSCT in first complete remission of acute leukemia; hence, it was introduced in patients with CML early in their disease, in first chronic phase $[8-10,18]$. 
The first allogeneic HSCT for CML was reported to the European Group for Blood and Marrow Transplantation (EBMT) database in 1975 from France, soon to be followed in 1978 by a patient from Switzerland and by 10 patients in 1979 from France, Italy, and the UK (personal communication; EBMT database, Leiden NL). The concept proved to be right and CML became soon the most frequent indication for an allogeneic HSCT in Europe and worldwide (Fig. 1) [11, 19]. Of note, as of June 2014, 3 of these 12 patients were reported to be alive at plus 35 years, one as lost to follow-up.

CML played a role model for HSCT in general in many aspects. CML did provide the first example for risk assessment with the EBMT risk score (see below)

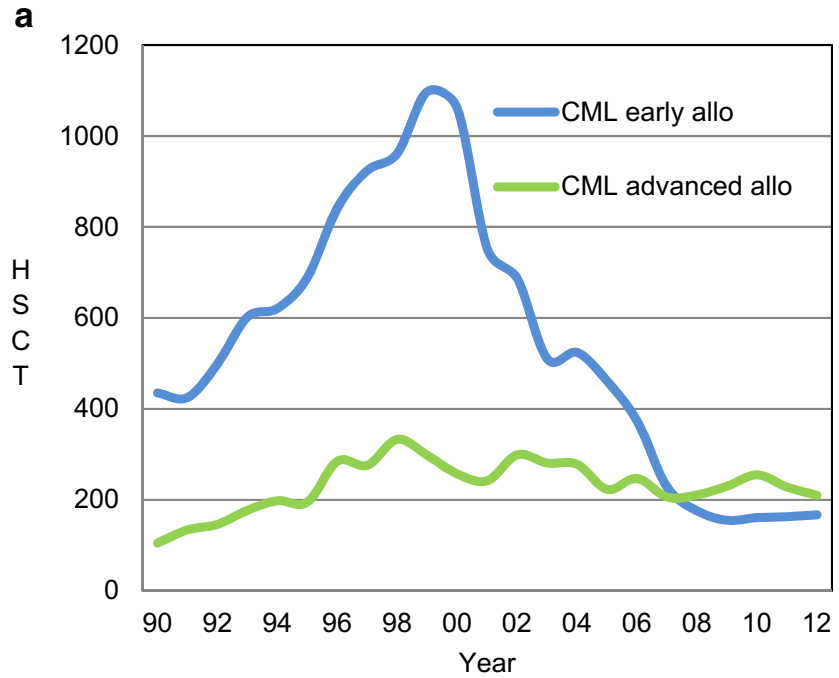

b

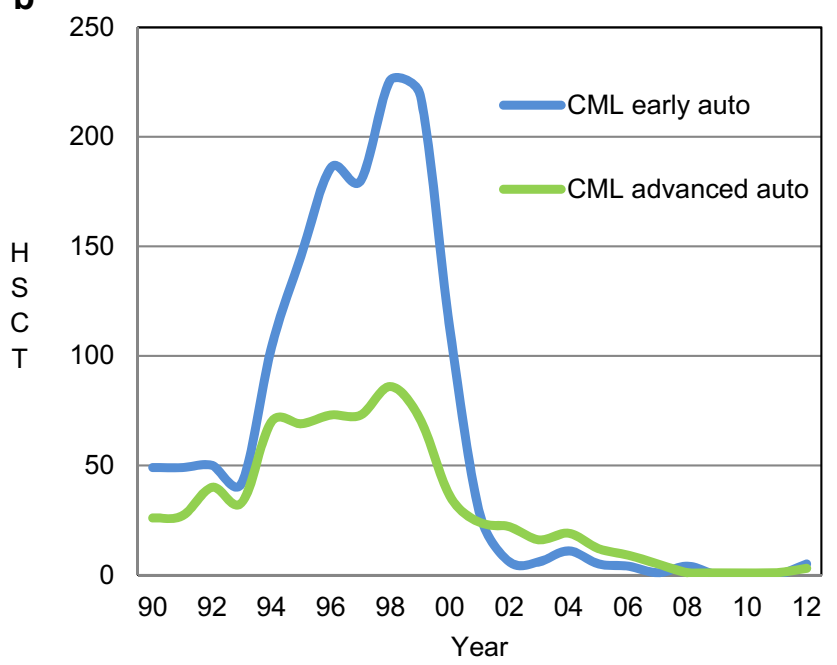

Fig. 1 Evolution of HSCT in Europe from 1990 to 2012. The graph illustrates increase and decrease of absolute numbers of allogeneic (Fig. 1a) and autologous (Fig. 1b) HSCT in Europe over time. In blue early disease (first chronic phase), in green advanced disease stage at time of HSCT (accelerated phase or blast crisis). a Evolution of allogeneic HSCT. b Evolution of autologous HSCT
[20-22]. It became clear that disease stage was more important than bulk of the disease. Splenectomy, considered initially as essential showed no advantage, nor did splenic irradiation [23]. CML was the first disease to demonstrate a consistent graft-versus-leukemia effect. Relapse risk was highest after $\mathrm{T}$ cell depletion in CML compared to other diseases, in contrast, donor lymphocyte infusion (DLI) proved to be the most powerful tool in CML. CML paved the way for reduced intensity conditioning, specifically with the additional role of preemptive DLI [24-26]. Last but not least, in no other disease became the impact of macroeconomic factors on use of HSCT as clear as in CML. Rates of HSCT for CML dropped already in the year 2000, 2 years before the release of imatinib in high income countries, illustrating how expectations drive medical decision making. They remained at a stable level in middle and low income countries where costs of drug therapy became higher than costs for a transplant $[11,19,27-30]$.

CML showed as well a role model for autologous HSCT. It was introduced in Europe early on, almost simultaneously with allogeneic HSCT. The first patient was reported to the EBMT database in 1979 from France, to be followed by 4 patients in 1980, from France as well. None of them stayed alive. The concept was clear, restore chronic phase in patients with advanced disease through stem cells obtained in early phase. Pilot studies proved to be promising and led to the design of several multicenter prospective randomized trials in Europe [31, 32]. None was completed; the introduction of the TKI ended these trials prematurely and the answer about the potential role of autologous HSCT remains open. At least, a retrospective meta-analysis of six multicentre trials in Europe and the US showed no advantage of such a procedure compared to concurrent drug treatment [33]. Numbers of autologous HSCT almost vanished away since 2006 [11] (Fig. 1).

\section{Current status in 2014}

Data from the EBMT activity survey report a total of 377 allogeneic HSCT for CML in 2012, 167 in early phase of the disease, 210 in advanced phase from 35 countries, and 8 autologous HSCT, 5 in early disease, 3 in advanced phase. Their distribution over disease stage, donor type, and stem cell source is illustrated in Table 1. Compared to previous years, total numbers remained stable.

Allogeneic HSCT were performed in 35 countries. There were significant differences in transplant rates (numbers of HSCT per 10 million inhabitants) between reporting countries (Fig. 2). They ranged from none to more than 10 in Belgium, Estonia, Finland, Sweden, and Switzerland. 
Table 1 HSCT for CML in Europe 2013 (preliminary data)

\begin{tabular}{|c|c|c|c|c|c|c|c|c|c|}
\hline & \multicolumn{7}{|c|}{ Allogeneic HSCT } & \multirow{3}{*}{$\begin{array}{l}\text { Autologous HSCT } \\
\text { Total }\end{array}$} & \multirow[t]{3}{*}{ Total } \\
\hline & \multicolumn{3}{|l|}{ Donor type } & \multicolumn{3}{|c|}{ Stem cell source } & \multirow[t]{2}{*}{ Total } & & \\
\hline & Syngeneic & Family & Unrelated & $\mathrm{BM}$ & $\mathrm{PB}$ & $\mathrm{CB}$ & & & \\
\hline $\mathrm{cP}$ & 0 & 60 & 80 & 34 & 102 & 4 & 140 & 0 & 140 \\
\hline Not cP & 0 & 78 & 117 & 32 & 157 & 6 & 195 & 3 & 198 \\
\hline Total & 0 & 138 & 197 & 66 & 259 & 10 & 335 & 3 & 338 \\
\hline
\end{tabular}

\section{Outcome of HSCT for CML}

Factors associated with outcome

HSCT has been and still is associated with significant early and late transplant-related mortality. In the early days, mortality appeared erratic, with some young patients dying, others surviving. In the mid-eighties of last century, it became apparent that outcome was related to specific pretransplant criteria, independent of transplant technology. This was especially important for patients with CML who faced the difficult decision to make, an early transplant with the significant risk for immediate mortality versus the risk of blastic transformation with minimal chances for rescue with HSCT. The EBMT risk score, based on five pretransplant factors did permit a rapid assessment on a scale from $0-$ VII at the physician's desk and gained rapid acceptance (Table 2). The risk score was validated in several independent cohorts and proved to be valid, with some minor modifications, for all acquired hematological disorders and for autologous HSCT as well [20-22].

The difficulty in risk assessment lies in the fact that some factors such as disease stage have congruent impact on the two key endpoints, transplant-related mortality and relapse, hence affect overall survival uniformly in the same direction; others have discordant effects. The net result might then depend on the sum of all other risk factors. $T$ cell depletion reduces the risk of graft-versus-host disease but increases the risk of relapse. The net benefit on overall survival will differ between patients transplanted in early disease compared to those transplanted in advanced disease stage. Reduced intensity might be of benefit in an older patient with comorbidities but early disease; it might be of no benefit in the same patient with no comorbidities but advanced disease (Table 3) [20-22].

As a general concept, risk factors act additively but not in a symmetrical way. A negative CMV serostatus might further improve outlook for a low-risk patient but will have no additional beneficial effect in a high-risk patient; in contrast, a reduced Karnofsky score might be of minimal impact in a low-risk patient but deleterious in a high-risk patient. Hence, the general statement that the probability of survival after an allogeneic HSCT for CML at 5 years is $60 \%$ is of limited value; it might range from more than $90 \%$ to less than $5 \%$. As we will see below, integration of all elements, including macroeconomic factors of patient's location, should impact on choice of transplant technique and the final decision to proceed with HSCT or to abstain from it [34-39].

\section{Impact of pretransplant treatment}

Most patients will have pretreatment for their CML before HSCT. Earlier studies indicated a higher transplantrelated mortality in patients pretreated with busulfan compared to hydroxyurea and in patients given interferon alpha up to the day of the transplant. Today, all patients will have had TKI before their transplant. There are clear indications that no type of TKI given before or after the transplant has a deleterious effect on outcome after HSCT; in one study, results appeared even better for patients with TKI prior to HSCT. In contrast, type of response to TKI therapy will impact on post transplant outcome with a good outcome for patients intolerant to TKI but with a higher likelihood of worse outcome for those who failed TKI therapy before HSCT [34, 40-45].

\section{Impact of HSCT methodology}

Despite now 30 years of experience, the best conditioning regimen and the best graft-versus-host disease prevention method remains to be defined. No other conditioning has been documented to arrive at better long term overall survival than cyclophosphamide and total body irradiation or the combination of busulfan and cyclophosphamide, no other graft-versus-host disease prevention method than the combination of cyclosporine and short methotrexate [8]. Reduced intensity conditioning has extended application of HSCT to elderly patients or to those with comorbidities [26]. In a large observational retrospective study by the CIBMTR, it showed a better overall survival in elderly patients compared to nonmyeloablative conditioning; no comparison was made 
a

\section{HSCT - rates in Europe 1999}

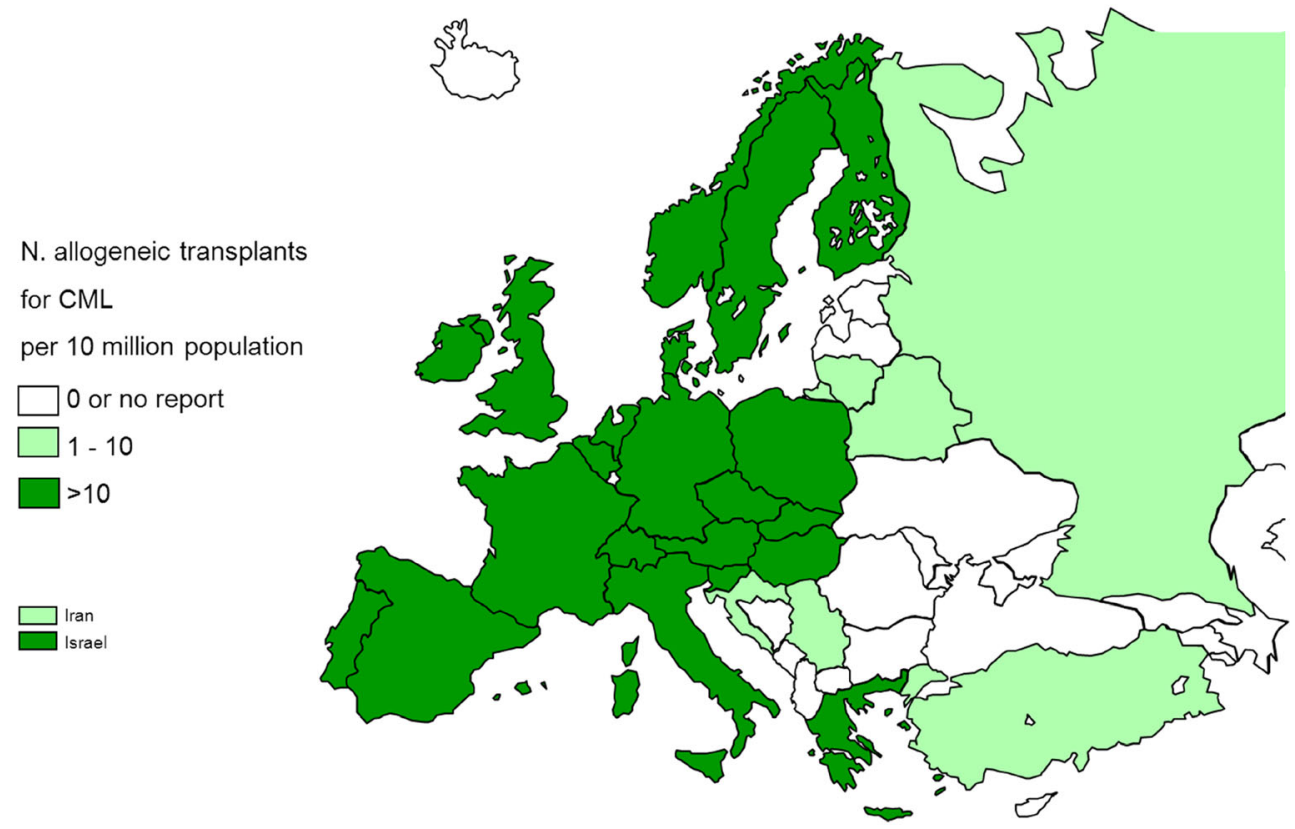

b

\section{HSCT - rates in Europe 2012}

N. allogeneic transplants for $\mathrm{CML}$

per 10 million population

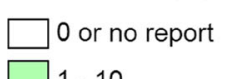

$1-10$

$>10$<smiles>C1CCCCC1</smiles>

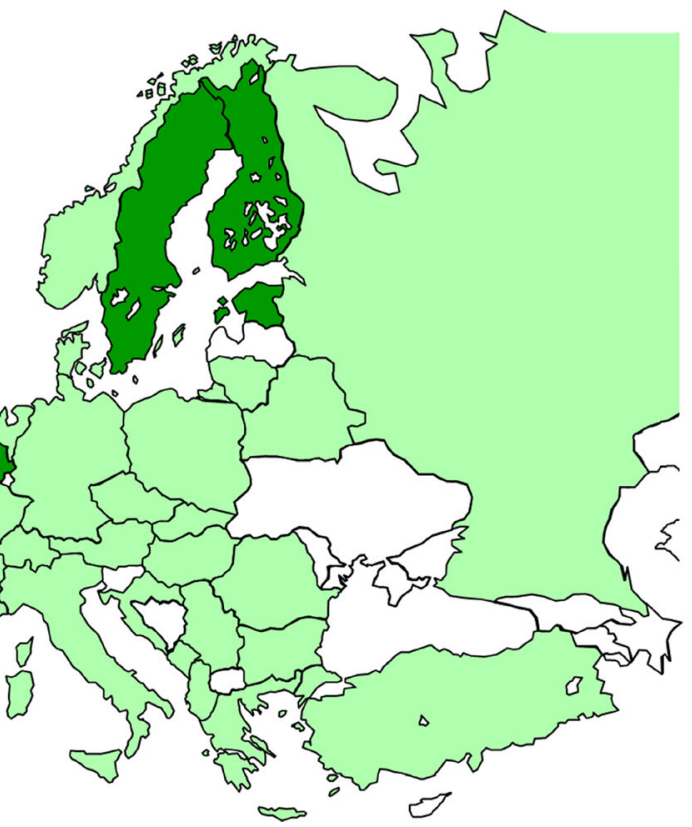

Fig. 2 Transplant rates in Europe 1999 and 2012. The figure depicts number of HSCT per 10 million inhabitants and illustrates the decrease in transplant rates for CML over time, in contrast to the transplant rates for all indications in general. It depicts as well the vast heterogeneity between

countries. a Transplant rates for CML in 1999. b Transplant rates for CML in 2012. a Transplant rates for all allogeneic indications in 1999. a Transplant rates for all allogeneic indications in 2012

with standard conditioning [42]. Bone marrow as stem cell source appears to be of advantage in early low-risk disease, peripheral blood in advanced disease [46, 47].
Of general importance to note, there are no indications that impact of transplant technology in CML differs from that in any other disease treated with HSCT $[8,15,48]$. 
C

\section{HSCT - rates in Europe 1999}

N. allogeneic transplants per 10 million population

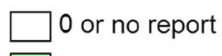

$\square 1$ - 10

$>10$

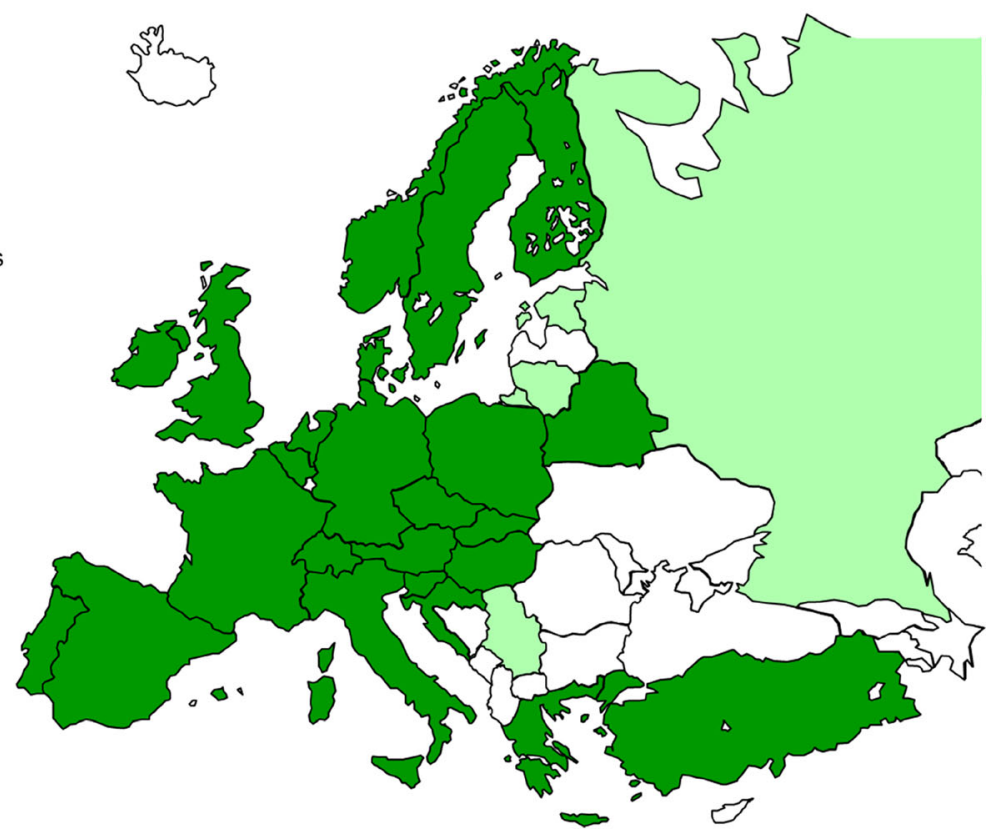

d

\section{HSCT - rates in Europe 2012}

N. allogeneic transplants per 10 million population

$\square 0$ or no report

$\square$ - 10

$>10$

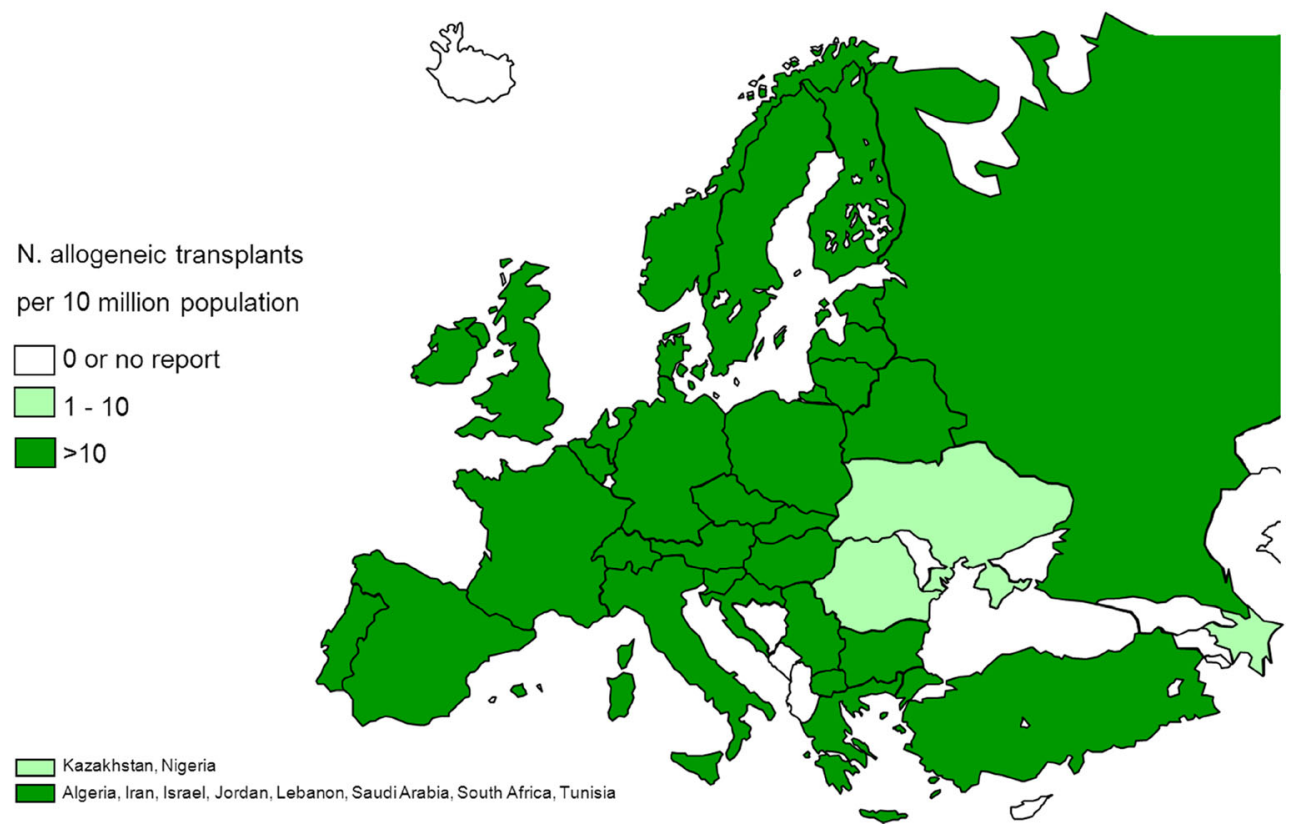

Fig. 2 (continued)

Graft-versus-host-graft-versus-leukemia effects

There is no doubt about the astonishing graft-versusleukemia effects observed in CML as documented by the powerful effects of DLI [25, 43]. Complete and lasting molecular remissions can be obtained with even one infusion of cells, some without any signs of graftversus-host disease. Many attempts have been made to exploit this effect better; so far, no study has proven to separate graft-versus-host from graft-versus-leukemia 
Table 2 EBMT risk score

\begin{tabular}{|c|c|c|c|}
\hline & Score points & & \\
\hline Risk factor & 0 & 1 & 2 \\
\hline Age & $<20$ years & $20-40$ years & $>40$ years \\
\hline Disease stage & Chronic phase & Other & Blast crisis \\
\hline Time interval diagnosis-transplant & $<12$ months & $>12$ months & - \\
\hline Donor type & HLA-identical sibling & Other & - \\
\hline Gender combination & Other & Female donor for male recipient & - \\
\hline
\end{tabular}

effects in advance. The net detrimental effects of graftversus-host reactions still outweigh the benefits [8].

Table 3 Risk factors in HSCT

\begin{tabular}{|c|c|c|c|}
\hline Risk factor & $\begin{array}{l}\text { Transplant-related } \\
\text { mortality }\end{array}$ & Relapse & $\begin{array}{l}\text { Overall } \\
\text { surviva }\end{array}$ \\
\hline \multicolumn{4}{|l|}{ Disease } \\
\hline Disease stage, advanced & $\uparrow$ & $\uparrow$ & $\downarrow$ \\
\hline Pretreatment & $\uparrow$ & $\uparrow$ & $\uparrow$ \\
\hline \multicolumn{4}{|l|}{ Time interval Dx-Tx } \\
\hline$<12$ months & $\downarrow$ & $\downarrow$ & $\uparrow$ \\
\hline \multicolumn{4}{|l|}{ Patient } \\
\hline Age, higher & $\uparrow$ & $\uparrow$ & $\downarrow$ \\
\hline Gender, female & $\downarrow$ & $\leftrightarrow$ & $\uparrow$ \\
\hline Karnofsky score $<90$ & $\uparrow$ & $\leftrightarrow$ & $\downarrow$ \\
\hline Comorbidity present & $\uparrow$ & $\leftrightarrow$ & $\downarrow$ \\
\hline CMV status & $\uparrow$ & $\downarrow$ & $\downarrow$ \\
\hline Cytokine polymorphisms & $\uparrow$ & $\uparrow$ & $\uparrow$ \\
\hline \multicolumn{4}{|l|}{ Donor } \\
\hline Syngeneic & $\downarrow$ & $\uparrow$ & $\uparrow$ \\
\hline HLA identical sibling & $\leftrightarrow$ & $\leftrightarrow$ & $\leftrightarrow$ \\
\hline Matched unrelated & $\uparrow$ & $\downarrow$ & $\leftrightarrow$ \\
\hline Mismatched & $\uparrow$ & $\downarrow$ & $\downarrow$ \\
\hline Gender FDMR & $\uparrow$ & $\downarrow$ & $\downarrow$ \\
\hline \multicolumn{4}{|l|}{ Stem cell source } \\
\hline BM, early disease & $\downarrow$ & $\leftrightarrow$ & $\leftrightarrow$ \\
\hline $\mathrm{PB}$, late disease & $\downarrow$ & $\downarrow$ & $\uparrow$ \\
\hline Cord blood & $\uparrow$ & $\uparrow$ & $\downarrow$ \\
\hline \multicolumn{4}{|l|}{ Conditioning } \\
\hline Reduced & $\downarrow$ & $\uparrow$ & $\uparrow$ \\
\hline \multicolumn{4}{|l|}{ GvHD prevention } \\
\hline $\mathrm{T}$ cell depletion & $\uparrow$ & $\uparrow$ & $\downarrow$ \\
\hline \multicolumn{4}{|l|}{ Macroeconomic factors } \\
\hline Team accreditation status + & $\downarrow$ & $\downarrow$ & $\uparrow$ \\
\hline Center experience greater & $\downarrow$ & $\downarrow$ & $\uparrow$ \\
\hline GNI/capita country high & $\downarrow$ & $\downarrow$ & $\uparrow$ \\
\hline $\begin{array}{l}\text { Pretreatment in experienced } \\
\text { center }\end{array}$ & $\downarrow$ & $\downarrow$ & $\uparrow$ \\
\hline
\end{tabular}

HSCT versus non-transplant therapy studies

No study has ever compared in a randomized way outcome after a transplant or a non-transplant strategy for patients with CML and an identified donor. Most likely, such a study will never be done. Hence, all recommendations depend on interpretation of comparative outcome data. The question appeared clear in the early days of allogeneic HSCT when no drug therapy was available to induce a $\mathrm{BCR} / \mathrm{ABL}$ negative state. The question about long-term outcome arose first time with the introduction of interferon alpha [49]. HSCT was still considered treatment of choice. The hypothesis prevailed that HSCT would be associated with early mortality but a subsequent survival benefit which could compensate for the "early years of life lost". The German CML study group did test this hypothesis in a prospective study, the CML III trial. Availability of a matched family donor was used as "genetic randomization". In this study with 349 patients, survival was significantly better after a median observation time of 8 years in patients on drug treatment. The conclusions arrived at already in times of TKI therapy were clear: "The general recommendation of HSCT as first-line treatment option in chronic phase CML can no longer be maintained" [50].

These result formed the basis for the subsequent European leukemiaNet (ELN) guidelines on the use of HSCT in TKItreated patients (see below) [50]. It became neglected that the CML III study was followed by the CML IIIa trial which did integrate the then known EBMT risk score factors. Teams were urged to proceed to transplant within the first year and to abstain from interferon use in the 3 months preceding the transplant. A recent comparison between the CML III and IIIA study clearly indicated a major improvement in outcome in the latter [51]. It will be important to see the survival data from that study at 10 years observation time. No study so far compared HSCT systematically with TKI treatment, but the CML IV study did permit early HSCT in this TKI-based study. Overall survival of 84 patients (median age, 37 years) with HSCT either first line (19 patients) or after imatinib failure (37 patients in CP, 28 patients in AP) was 88, 94, and $59 \%$; transplant-related mortality was $8 \%$; chronic graftversus-host disease occurred in $46 \%$. Of note, overall survival of the patients transplanted in $\mathrm{CP}$ was not different from that 
of the concomitantly imatinib treated patient cohort. No early excess mortality was noted [45]. Several other retrospective studies have compared single center or national study populations treated concomitantly with TKI or allogeneic HSCT. There were some conflicting results. Most comparisons relate to patients in initially early phase CML. Few studies compared outcome after BC in a comparative way. The general consensus appears that allogeneic HSCT offers a reasonable outcome even in accelerated phase or blast crisis [52-57].

Several studies did initiate in the nineties a prospective randomized comparison of autologous HSCT with drug treatment. None of the studies was completed; they were aborted prematurely at the time of imatinib introduction. A retrospective meta-analysis of six studies showed no advantage for the patients with autologous HSCT; hence, autologous HSCT has been largely abandoned as treatment for patients with $\mathrm{CML}$ [33].

\section{Current recommendations}

\section{European leukemiaNet}

The current ELN recommendations consider allogeneic HSCT, define when a donor search should be undertaken, and recommend at given states allogeneic HSCT [50]. The key elements include the following statements: "Allo SCT will continue to be an important treatment of patients who fail to respond durably to TKIs." "It seems reasonable that for patients in CP, transplant should be reserved for those who are resistant or intolerant to at least one second generation TKI." "Allo SCT is recommended for all BP patients and for the AP patients who do not achieve an optimal response." "AP and $\mathrm{BP}$ as a progression from $\mathrm{CP}$ in TKI pretreated patients: allo SCT in all patients."

\section{Other recommendations}

The NCI recommendations (www.cancer.gov/cancertopics/ $\mathrm{pdq} /$ treatment/CML/Patient/page4) remain open. They list HSCT among six types of standard treatment, targeted therapy, chemotherapy, biologic therapy, high-dose chemotherapy with stem cell transplant, donor lymphocyte infusion (DLI), and surgery, without specifications.

The German Onkopedia (www.dgho-onkopedia.de/de/ onkopedia/leitlinien/cml/index_html? searchterm $=\mathrm{cml}$ ) webpage is very detailed and follows in principle the ELN recommendations but relate more on disease risk aspects than transplant risks.

The UK recommendations (www.patient.co.uk/doctor/ chronic-myeloid-leukaemia-pro) are vaguer about the timing of allogeneic HSCT but integrate transplant risk: AlloSCT should ideally be undertaken in the chronic phase of CML when it is associated with 3- to 5-year survival rates of 40$80 \%$ and 10 -year survival rates of $30-60 \%$. The optimal time of transplantation is controversial but thought to be up to 24 months following diagnosis. Transplantation-related mortality ranges from 5 to $50 \%$ depending on factors including the patient's age, donor origin (related versus unrelated), degree of HLA matching, host cytomegalovirus status, use of conditioning regimens, and institutional expertise.

\section{Critical appraisal}

Listed are just four of manifold international recommendations for treatment of CML and integration of HSCT. They all mention allogeneic HSCT, none autologous HSCT. They all agree on the major role of allogeneic HSCT in blast crisis; they differ slightly in their view on the place of allogeneic HSCT in early disease and in accelerated phase. They are in line with several other published expert reviews [2, 6, 58-61]. But most focus with few exceptions primarily on disease risk. They consider primarily a failed response to first and second generation TKI or a mutation with primary resistance such as the T3 151 mutation as indication. Several separate as well donor search into search for a family donor first, for an unrelated donor at a later stage. Transplant risk, with the exception of the UK recommendation is vaguely specified.

\section{Concluding remarks}

The introduction of TKI as targeted therapy has eased and improved the treatment of CML in an unprecedented way. It has increased the understanding of the disease, changed attitudes but complicated decision trees. The astonishing results with TKI have interrupted many comparative trials and focused multicenter research interests on comparative trials of different drugs. The ease of drug administration has as well shifted the patient community from major University centers towards decentralized medical practice. In parallel, interest in the HSCT community has shifted to questions of novel transplant technologies, much less on comparisons with non-HSCT approaches. As a consequence, no single study is currently listed which compares HSCT with non-HSCT treatment at any stage of the disease (https://clinicaltrials.gov/ct2/home; last assessed July 2nd 2014). It is unlikely that such comparative trials will soon follow. Hence, all recommendations are based on individual interpretation of past results. This will admittedly be influenced by the expectations of the expert.

Outcome of HSCT has substantially improved over the last decade, numbers of HLA typed unrelated donors has increased to more than 22 million worldwide and assessment of the likelihood to find a well-matched donor can be done today in a very short time. Improvement was greater for patients with early disease; it was substantially greater for 
patients transplanted in a JACIE accredited center in Europe [62]. Survival of patients under drug treatment with advanced disease in parallel was substantially better for those treated in a University affiliated center compared to those in a community practice [63]. And, there are no hints that quality of life is worse after HSCT for long term survivors [64, 65]. Some consequences could be drawn.

Current recommendations of professional organizations such as the ELN should consider integration of a quality management system into the treatment algorithm. HSCT should be integrated at diagnosis, with HLA typing, evaluation of the likelihood to find a donor and transplant risk assessment. In case of early failure, HSCT could be considered rapidly for those with minimal transplant risks; drug treatment changed for those without this option. The same will apply for those roughly five percent of patients with rapid transformation at any time and for those with failure to respond to second or third line therapy. The same applies for patients with blast crisis. Disease, transplant, and economic risks need to be assessed [21, 35, 37, 38, 66-68]. Patients with high transplant risks should not be entered into long-lasting unsuccessful donor searches to end with HSCT in desperation without any reasonable likelihood for success. Continued drug therapy, experimental approaches, or palliation might be the wiser option. A similar approach has been advised for acute myeloid leukemia [69]. In order to arrive at such a policy, patients and patient's advocacy groups need to be informed, cooperation has to be established between the local medical community and the transplant centers, professional organizations have to adapt recommendations within a quality management system and to collect and analyze the appropriate data. More patients will profit from a safe transplant; fewer patients will undergo a futile transplant procedure.

Conflict of interest The manuscript is solely written by the authors. A.G. declares no conflicts of interest; H.B. declares no conflicts of interest; J.P. declares no conflicts of interest.

\section{References}

1. Schiffer CA (2007) BCR-ABL tyrosine kinase inhibitors for chronic myelogenous leukemia. N Engl J Med 357(3):258-265

2. Jabbour E, Kantarjian H (2014) Chronic myeloid leukemia: 2014 update on diagnosis, monitoring, and management. Am J Hematol 89(5):547-556. doi:10.1002/ajh.23691

3. Hehlmann R (1998) A chance of cure for every patient with chronic myeloid leukemia? N Engl J Med 338(14):980-982. doi:10.1056/ NEJM199804023381409

4. O'Brien SG, Guilhot F, Larson RA, Gathmann I, Baccarani M, Cervantes F, Cornelissen JJ, Fischer T, Hochhaus A, Hughes T, Lechner K, Nielsen JL, Rousselot P, Reiffers J, Saglio G, Shepherd J, Simonsson B, Gratwohl A, Goldman JM, Kantarjian H, Taylor K, Verhoef G, Bolton AE, Capdeville R, Druker BJ, Investigators IRIS (2003) Imatinib compared with interferon and low-dose cytarabine for newly diagnosed chronic-phase chronic myeloid leukemia. $\mathrm{N}$ Engl J Med 348(11):994-1004

5. Hughes TP, Hochhaus A, Branford S, Müller MC, Kaeda JS, Foroni L, Druker BJ, Guilhot F, Larson RA, O'Brien SG, Rudoltz MS, Mone M, Wehrle E, Modur V, Goldman JM, Radich JP, IRIS investigators (2010) Long-term prognostic significance of early molecular response to imatinib in newly diagnosed chronic myeloid leukemia: an analysis from the International Randomized Study of Interferon and STI571 (IRIS). Blood 116(19):3758-3765. doi:10.1182/blood2010-03-273979

6. Jain N, O'Brien S (2013) The frontline treatment of chronic myeloid leukemia in the chronic phase: current clinical decisions and future prospects for treatment. Expert Rev Hematol 6(5):575-586. doi:10. 1586/17474086.2013.835697

7. Gugliotta G, Castagnetti F, Apolinari M, Pirondi S, Cavo M, Baccarani M, Rosti G (2014) First-line treatment of newly diagnosed elderly patients with chronic myeloid leukemia: current and emerging strategies. Drugs 74(6):627-643

8. Copelan EA (2006) Hematopoietic stem-cell transplantation. N Engl J Med 354:1813-1826

9. Appelbaum FR (2007) Hematopoietic-cell transplantation at 50. N Engl J Med 357:1472-1475

10. Speck B, Bortin MM, Champlin R, Goldman JM, Herzig RH, McGlave PB, Messner HA, Weiner RS, Rimm AA (1984) Allogeneic bone-marrow transplantation for chronic myelogenous leukaemia. Lancet 1(8378):665-668

11. Passweg JR, Baldomero H, Bregni M, Cesaro S, Dreger P, Duarte RF, Falkenburg JH, Kröger N, Farge-Bancel D, Gaspar HB, Marsh J, Mohty M, Peters C, Sureda A, Velardi A, Ruiz de Elvira C, Madrigal A (2013) European group for blood and marrow transplantation. Bone Marrow Transplant 48(9):1161-1167. doi:10.1038/bmt. 2013.51

12. Mackinnon S, Goldman JM (1987) Bone marrow transplantation for CML. Baillieres Clin Haematol 1(4):1055-1076

13. Moreau P, San Miguel J, Ludwig H, Schouten H, Mohty M, Dimopoulos M, Dreyling M (2013) ESMO guidelines working group. Multiple myeloma: ESMO clinical practice guidelines for diagnosis, treatment and follow-up. Ann Onco 24(Suppl 6):vi133vi137. doi:10.1093/annonc/mdt297

14. Engelhardt M, Terpos E, Kleber M, Gay F, Wäsch R, Morgan G, Cavo M, van de Donk N, Beilhack A, Bruno B, Johnsen HE, Hajek R, Driessen C, Ludwig H, Beksac M, Boccadoro M, Straka C, Brighen S, Gramatzki M, Larocca A, Lokhorst H, Magarotto V, Morabito F, Dimopoulos MA, Einsele H, Sonneveld P, Palumbo A (2014) European myeloma network. European myeloma network recommendations on the evaluation and treatment of newly diagnosed patients with multiple myeloma. Haematologica 99(2):232242. doi:10.3324/haematol.2013.099358

15. Gooley TA, Chien JW, Pergam SA, Hingorani S, Sorror ML, Boeckh M, Martin PJ, Sandmaier BM, Marr KA, Appelbaum FR, Storb R, McDonald GB (2010) Reduced mortality after allogeneic hematopoietic-cell transplantation. N Engl J Med 363(22):20912101. doi:10.1056/NEJMoa1004383

16. Gratwohl A, Brand R, McGrath E, van Biezen A, Sureda A, Ljungman P, Baldomero H, Chabannon C, Apperley J, Joint Accreditation Committee (JACIE) of the International Society for Cellular Therapy and the European Group for Blood and Marrow Transplantation, and the European Leukemia Net (2014) Use of the quality management system "JACIE" and outcome after hematopoietic stem cell transplantation. Haematologica 99(5):908-915

17. Fefer A, Einstein AB, Thomas ED, Buckner CD, Clift RA, Glucksberg H, Neiman PE, Storb R (1974) Bone-marrow transplantation for hematologic neoplasia in 16 patients with identical twins. N Engl J Med 290(25):1389-1393

18. Goldman JM, Apperley JF, Jones L, Marcus R, Goolden AW, Batchelor R, Hale G, Waldmann H, Reid CD, Hows J et al (1986) 
Bone marrow transplantation for patients with chronic myeloid leukemia. N Engl J Med 314(4):202-207

19. Gratwohl A, Schwendener A, Baldomero H et al (2010) Changes in the use of hematopoietic stem cell transplantation: a model for diffusion of medical technology. Haematologica 95:637-643

20. Gratwohl A, Hermans J, Goldman JM, Arcese W, Carreras E, Devergie A, Frassoni F, Gahrton G, Kolb HJ, Niederwieser D, Ruutu T, Vernant JP, de Witte T, Apperley J (1998) Risk assessment for patients with chronic myeloid leukaemia before allogeneic blood or marrow transplantation. Chronic leukemia working party of the European group for blood and marrow transplantation. Lancet 352(9134):1087-1092

21. Gratwohl A, Stern M, Brand R, Apperley J, Baldomero H, de Witte T, Dini G, Rocha V, Passweg J, Sureda A, Tichelli A, Niederwieser D (2009) Risk score for outcome after allogeneic hematopoietic stem cell transplantation: a retrospective analysis. Cancer 115(20):47154726. doi:10.1002/cner.24531

22. Gratwohl A (2012) The EBMT risk score. Bone Marrow Transplant 47(6):749-756

23. Gratwohl A, Goldman J, Gluckman E, Zwaan F (1985) Effect of splenectomy before bone-marrow transplantation on survival in chronic granulocytic leukaemia. Lancet 2(8467):1290-1291

24. Weiden PL, Sullivan KM, Flournoy N, Storb R, Thomas ED (1981) Antileukemic effect of chronic graft-versus-host disease: contribution to improved survival after allogeneic marrow transplantation. N Engl J Med 304(25):1529-1533

25. Kolb HJ, Mittermüller J, Clemm C, Holler E, Ledderose G, Brehm G, Heim M, Wilmanns W (1990) Donor leukocyte transfusions for treatment of recurrent chronic myelogenous leukemia in marrow transplant patients. Blood 76(12):2462-2465

26. Niederwieser D, Maris M, Shizuru JA, Petersdorf E, Hegenbart U, Sandmaier BM, Maloney DG, Storer B, Lange T, Chauncey T, Deininger M, Pönisch W, Anasetti C, Woolfrey A, Little MT, Blume KG, McSweeney PA, Storb RF (2003) Low-dose total body irradiation (TBI) and fludarabine followed by hematopoietic cell transplantation (HCT) from. HLA-matched or mismatched unrelated donors and postgrafting immunosuppression with cyclosporine and mycophenolatemofetil (MMF) can induce durable complete chimerism and sustained remissions in patients with hematological diseases. Blood 101(4):1620-1629

27. Gratwohl A, Baldomero H, Aljurf M et al (2010) Hematopoietic stem cell transplantation: a global perspective. JAMA 303(16):1617-1624

28. Gratwohl A, Baldomero H, Gratwohl M, Aljurf M, Bouzas LF, Horowitz M, Kodera Y, Lipton J, Iida M, Pasquini MC, Passweg J, Szer J, Madrigal A, Frauendorfer K, Niederwieser D, Worldwide Network of Blood and Marrow Transplantation (WBMT) (2013) Quantitative and qualitative differences in use and trends of hematopoietic stem cell transplantation: a Global Observational Study. Haematologica 98(8):1282-1290. doi:10.3324/haematol.2012. 076349

29. Pasquini MC (2012) Hematopoietic cell transplantation for chronic myeloid leukemia in developing countries: perspectives from Latin America in the post-tyrosine kinase inhibitor era. Hematology 17(Suppl 1):S79-S82

30. López-Hernández MA, Alvarado-Ibarra M, González-Avante CM (2011) Overall survival of chronic myeloid leukemia patients treated with related donor hematopoieticstemcell transplant or imatinib. Rev Invest Clin 63(5):494-499

31. Butturini A, Keating A, Goldman J, Gale RP (1990) Autotransplants in chronic myelogenous leukaemia: strategies and results. Lancet 335(8700):1255-1258

32. Reiffers J, Goldman J, Meloni G, Cahn JY, Gratwohl A (1994) Autologous stem cell transplantation in chronic myelogenous leukemia: a retrospective analysis of the European group for bone marrow transplantation. Chronic leukemia working party of the EBMT. Bone Marrow Transplant 14(3):407-410
33. Autograft Trials Collaboration CML (2007) Autologous stem cell transplantation in chronic myeloid leukaemia: a meta-analysis of six randomized trials. Cancer Treat Rev 33(1):39-47

34. Heim D, Gratwohl A (2008) Role of allogeneic transplantation in chronic myeloid leukemia. Expert Rev Hematol 1(1):41-50. doi:10. 1586/17474086.1.1.41

35. Sorror ML (2010) Comorbidities and hematopoietic cell transplantation outcomes. Hematology Am Soc Hemato lEduc Program 2010: 237-247

36. Spellman S, Setterholm M, Maiers M, Noreen H, Oudshoorn M, Fernandez-Vina M, Petersdorf E, Bray R, Hartzman RJ, Ng J, Hurley CK (2008) Advances in the selection of HLA-compatible donors: refinements in HLA typing and matching over the first 20 years of the National Marrow Donor Program Registry. Biol Blood Marrow Transplan 14:37-44

37. Latham K, Little AM, Madrigal JA (2014) An overview of HLA typing for hematopoietic stem cell transplantation. Methods Mol Biol 1109:73-85

38. Lown RN, Philippe J, Navarro W, van Walraven SM, PhilipsJohnson L, Fechter M, Pawson R, Bengtsson M, Beksac M, Field S, Yang H, Shaw BE (2014) Unrelated adult stem cell donor medical suitability: recommendations from the world marrow donor association clinical working group committee. Bone Marrow Transplant. doi:10.1038/bmt.2014.67

39. Green ML, Leisenring WM, Xie H, Walter RB, Mielcarek M, Sandmaier BM, Riddell SR, Boeckh M (2013) CMV reactivation after allogeneic. HCT and relapse risk: evidence for early protection in acute myeloid leukemia. Blood 122(7):1316-1324

40. Bar M, Radich J (2013) Maintenance therapy with tyrosine kinase inhibitors after transplant in patients with chronic myeloid leukemia. J Natl Compr Canc Netw 11(3):308-315

41. Oyekunle A, Zander AR, Binder M, Ayuk F, Zabelina T, Christopeit M, Stübig T, Alchalby H, Schafhausen P, Lellek H, Wolschke C, Müller I, Bacher U, Kröger N (2013) Outcome of allogeneic. SCT in patients with chronic myeloid leukemia in the era of tyrosine kinase inhibitor therapy. Ann Hematol 92(4):487-496

42. Warlick E, Ahn KW, Pedersen TL, Artz A, de Lima M, Pulsipher M, Akpek G, Aljurf M, Cahn JY, Cairo M, Chen YB, Cooper B, Deol A, Giralt S, Gupta V, Khoury HJ, Kohrt H, Lazarus HM, Lewis I, Olsson R, Pidala J, Savani BN, Seftel M, Socié G, Tallman M, Ustun C, Vij $\mathrm{R}$, Vindeløv L, Weisdorf D (2012) Reduced intensity conditioning is superior to nonmyeloablative conditioning for older chronic myelogenous leukemia patients undergoing hematopoietic cell transplant during the tyrosine kinase inhibitor era. Blood 119(17):4083-4090

43. Shanavas M, Messner HA, Kamel-Reid S, Atenafu EG, Gupta V, Kuruvilla J, Kim D, Uhm J, Lambie A, Ellis L, Lipton JH (2014) A comparison of long-term outcomes of donor lymphocyte infusions and tyrosine kinase inhibitors in patients with relapsed CML after allogeneic hematopoietic cell transplantation. Clin Lymphoma Myeloma Leuk 14:87-92

44. Lee SJ, Kukreja M, Wang T, Lee SJ, Kukreja M, Wang T, Giralt SA, Szer J, Arora M, Woolfrey AE, Cervantes F, Champlin RE, Gale RP, Halter J, Keating A, Marks DI, McCarthy PL, Olavarria E, Stadtmauer EA, Abecasis M, Gupta V, Khoury HJ, George B, Hale GA, Liesveld JL, Rizzieri DA, Antin JH, Bolwell BJ, Carabasi MH, Copelan E, Ilhan O, Litzow MR, Schouten HC, Zander AR, Horowitz MM, Maziarz RT (2008) Impact of prior imatinib mesylate on the outcome of hematopoietic cell transplantation for chronic myeloid leukemia. Blood 112(8):3500-3507

45. Saussele S, Lauseker M, Gratwohl A, Beelen DW, Bunjes D, Schwerdtfeger R, Kolb HJ, Ho AD, Falge C, Holler E, Schlimok G, Zander AR, Arnold R, Kanz L, Dengler R, Haferlach C, Schlegelberger B, Pfirrmann M, Muller MC, Schnittger S, Leitner A, Pletsch N, Hochhaus A, Hasford J, Hehlmann R (2010) Allogeneic hematopoietic stem cell transplantation (allo SCT) for chronic myeloid leukemia in the imatinib era: evaluation of its impact 
within a subgroup of the randomized German CML Study IV. Blood 115(10):1880-1885. doi:10.1182/blood-2009-08-237115

46. Holtick U, Albrecht M, Chemnitz JM, Theurich S, Skoetz N, Scheid C, von Bergwelt-Baildon M (2014) Bone marrow versus peripheral blood allogeneic haematopoietic stem cell transplantation for haematological malignancies in adults. Cochrane Database Syst Rev 4, CD010189. doi:10.1002/14651858.CD010189.pub2

47. Eapen M, Logan BR, Appelbaum FR et al (2014) Long-term survival after transplantation of unrelated donor peripheral blood or bone marrow hematopoietic cells for hematologic malignancy. Biol Blood Marrow Transplant. doi:10.1016/j.bbmt.2014.09.006

48. Khoury HJ, Kukreja M, Goldman JM, Wang T, Halter J, Arora M, Gupta V, Rizzieri DA, George B, Keating A, Gale RP, Marks DI, McCarthy PL, Woolfrey A, Szer J, Giralt SA, Maziarz RT, Cortes J, Horowitz MM, Lee SJ (2012) Prognostic factors for outcomes in allogeneic transplantation for CML in the imatinib era: a CIBMTR analysis. Bone Marrow Transplant 47(6):810-816

49. Hehlmann R, Heimpel H, Hasford J, Kolb HJ, Pralle H, Hossfeld DK, Queisser W, Loffler H, Hochhaus A, Heinze B et al (1994) Randomized comparison of interferon-alpha with busulfan and hydroxyurea in chronic myelogenous leukemia. The German CML Study Group. Blood 84(12):4064-4077

50. Hehlmann R, Berger U, Pfirmann M, Heimpel H, Hochhaus A, Hasford J, Kolb HJ, Lahaye T, Maywald O, Reiter A, Hossfeld DK, Huber C, Loffler H, Pralle H, Queisser W, Tobler A, Nerl C, Solenthaler M, Goebeler ME, Griesshammer M, Fischer T, Kremers $\mathrm{S}$, Eimermacher H, Pfreundschuh M, Hirschmann WD, Lechner K, Wassmann B, Falge C, Kirchner HH, Gratwohl A (2007) Drug treatment is superior to allografting as first-line therapy in chronic myeloid leukemia. Blood 109(11):4686-4692. doi:10.1182/blood-200611-055186

51. Pfirmann M, Saussele S, Hochhaus A, Reiter A, Berger U, Hossfeld DK, Nerl C, Scheid C, Spiekermann K, Mayer J, Hellmann A, Lechner K, Falge C, Sayer HG, Bunjes D, Ganser A, Beelen DW, Baldomero H, Schanz U, Heimpel H, Kolb HJ, Hasford J, Gratwohl A, Hehlmann $\mathrm{R}$; for the SchweizerischeArbeitsgemeinschaftfüKlinischeForschung (SAKK) and the German CML Study Group (2014) Explaining survival differences between two consecutive studies with allogeneic stem cell transplantation in patients with chronic myeloid leukemia J Cancer Res Clin Oncol Apr 10

52. Jiang Q, Xu LP, Liu DH, Liu KY, Gale RP, Zhang MJ, Jiang B, Zhang XH, Wang Y, Chen SS, Zhao XY, Chen H, Jiang H, Chen YH, Han W, Qin YZ, Liu YR, Lai YY, Lv M, Huang XJ (2013) Imatinib results in better outcomes than. HLA-identical sibling transplants in young persons with newly diagnosed chronic-phase chronic myelogenous leukemia. Leukemia 27(12):2410-2413. doi:10.1038/leu.2013.159

53. Liu YC, Hsiao HH, Chang CS, Liu TC, Yang WC, Hsu JF, Huang CT, Cho SF, Wu CH, Tsai YF, Lin SF (2013) Outcome of allotransplants in patients with chronic-phase chronic myeloid leukemia following imatinib failure: prognosis revisited. Anticancer Res 33(10):4663-4667

54. Hamidieh AA, Ansari S, Darbandi B, Soroush A, Arjmandi Rafsanjani K, Alimoghaddam K, Bahosh G, Behfar M, Ghavamzadeh A (2013) The treatment of children suffering from chronic myelogenous leukemia: a comparison of the result of treatment with imatinib mesylate and allogeneic hematopoietic stem cell transplantation. Pediatr Transplant 17(4):380-386

55. Tantiworawit A, Power MM, Barnett MJ, Hogge DE, Nantel SH, Nevill TJ, Shepherd JD, Song KW, Sutherland HJ, Toze CL, AbouMourad YR, Narayanan S, Broady RC, Forrest DL (2012) Long-term follow-up of patients with chronic myeloid leukemia in chronic phase developing sudden blast phase on imatinib therapy. Leuk Lymphoma 53(7):1321-1326
56. Jiang Q, Xu LP, Liu DH, Liu KY, Chen SS, Jiang B, Jiang H, Chen H, Chen YH, Han W, Zhang XH, Wang Y, Qin YZ, Liu YR, Lai YY, Huang XJ (2011) Imatinib mesylate versus allogeneic hematopoietic stem cell transplantation for patients with chronic myelogenous leukemia in the accelerated phase. Blood 117(11):3032-3040

57. Hehlmann R (2012) How I treat CML blast crisis. Blood 120(4):737-747

58. O'Hare T, Zabriskie MS, Eiring AM, Deininger MW (2012) Pushing the limits of targeted therapy in chronic myeloid leukaemia. Nat Rev Cancer 12(8):513-526. doi:10.1038/nrc3317

59. Pavlů J, Apperley JF (2013) Allogeneic stem cell transplantation for chronic myeloid leukemia. Curr Hematol Malig Rep 8(1):43-51. doi: 10.1007/s11899-012-0149-7

60. Benyamini N, Rowe JM (2013) Is there a role for allogeneic transplantation in chronic myeloid leukemia? Expert Rev Hematol 6(6): 759-765

61. Kantarjian H, O'Brien S, Jabbour E, Garcia-Manero G, QuintasCardama A, Shan J, Rios MB, Ravandi F, Faderl S, Kadia T, Borthakur G, Huang X, Champlin R, Talpaz M, Cortes J (2012) Improved survival in chronic myeloid leukemia since the introduction of imatinib therapy: a single-institution historical experience. Blood 119(9):1981-1987

62. Gratwohl A, Brand R, Niederwieser D et al (2011) Introduction of a quality management system and outcome after hematopoietic stemcell transplantation. J Clin Oncol 29:1980-1986

63. Lauseker M, Hasford J, Pfirrmann M, Hehlmann R, German CML, Group S (2014) The impact of health care settings on survival time of patients with chronic myeloid leukemia. Blood 123(16):2494-2496. doi:10.1182/blood-2013-11-539742

64. Baccarani M, Deininger MW, Rosti G, Hochhaus A, Soverini S, Apperley JF, Cervantes F, Clark RE, Cortes JE, Guilhot F, HjorthHansen H, Hughes TP, Kantarjian HM, Kim D-W, Larson RA, Lipton JH, Mahon F-X, Martinelli G, Mayer J, Müller MC, Niederwieser D, Pane F, Radich JP, Rousselot P, Saglio G, Saußele S, Schiffer C, Silver R, Simonsson B, Steegmann J-L, Goldman JM, Hehlmann R (2013) European LeukemiaNet recommendations for the management of chronic myeloid leukemia: 2013. Blood 122(6): 872-884. doi:10.1182/blood-2013-05-501569

65. Mo XD, Jiang Q, Xu LP, Liu DH, Liu KY, Jiang B, Jiang H, Chen H, Chen YH, Zhang XH, Han W, Wang Y, Huang XJ (2014) Healthrelated quality of life of patients with newly diagnosed chronic myeloid leukemia treated with allogeneic hematopoietic SCT versus imatinib. Bone Marrow Transplant 49(4):576-580. doi:10.1038/ bmt.2013.232

66. Pavey T, Hoyle M, Ciani O, Crathorne L, Jones-Hughes T, Cooper C, Osipenko L, Venkatachalam M, Rudin C, Ukoumunne O, Garside R, Anderson R (2012) Dasatinib, nilotinib and standard-dose imatinib for the first-line treatment of chronic myeloid leukaemia: systematic reviews and economic analyses. Health Technol Assess 16(42):1277. doi:10.3310/hta16420

67. Experts in Chronic Myeloid Leukemia (2013) The price of drugs for chronic myeloid leukemia (CML) is a reflection of the unsustainable prices of cancer drugs: from the perspective of a large group of CML experts. Blood 121(22):4439-4442. doi:10.1182/blood-2013-03490003

68. Yeung KY, Gooley TA, Zhang A, Raftery AE, Radich JP, Oehler VG (2012) Predicting relapse prior to transplantation in chronic myeloid leukemia by integrating expert knowledge and expression data. Bioinformatics 28(6):823-830

69. Cornelissen JJ, Gratwohl A, Schlenk RF et al (2012) The European LeukemiaNet AML Working Party consensus statement on allogeneic HSCT for patients with AML in remission: an integrated-risk adapted approach. Nat Rev Clin Oncol 9:579-590 